\title{
Artigos
}

\author{
Naara Luna \\ Universidade Federal do Rio de Janeiro
}

\section{Fetos anencefálicos e embriões para pesquisa: sujeitos de direitos?}

\begin{abstract}
Resumo: O artigo analisa a emergência de sujeitos sociais em seres antes embutidos na figura materna, depois definidos e circunscritos pela biomedicina: os embrióes extracorporais formados por fertilização in vitro e os fetos anencefálicos. Os embriões estiveram no centro de controvérsia nos debates para a aprovação da Lei de Biossegurança, que autorizou o seu uso em pesquisa. Já os fetos anencefálicos foram objeto do debate quanto à possibilidade de ampliação dos permissivos para o aborto. Analisando notícias da grande imprensa, principalmente em levantamento sistemático do jornal O Globo, entre 2000 e 2005, o objetivo é retratar os argumentos que integraram esses debates. Os argumentos que justificam ou recusam o uso de embriões para pesquisa e a antecipação de parto de anencéfalo coincidem em vários pontos porque são tributários da mesma configuração de valores e se fundamentam na figura de pessoa: o indivíduo como valor segundo Dumont.

Palavras-chave: embrião humano; anencéfalo; aborto; vida; pessoa.
\end{abstract}

Copyright (C) 2009 by Revista Estudos Feministas.
O artigo analisa a emergência de sujeitos sociais em seres antes embutidos na figura materna, depois definidos e circunscritos pela biomedicina: os embriões extracorporais formados por fertilização in vitro (FIV) e os fetos anencefálicos. Por ocasião dos debates para a aprovação da nova Lei de Biossegurança, os embriões de laboratório estiveram no centro de uma polêmica quanto à possibilidade de seu uso como material de pesquisa para a produção de células-tronco, almejando-se a aplicação futura em terapias. Os fetos anencefálicos foram objeto de polêmica diante das idas e vindas nas deliberações de várias cortes, chegando ao Supremo Tribunal Federal, que devia conceder ou negar autorização para a interrupção desse tipo de gestação. Embora se trate de objetos distintos (um ente de laboratório e um feto malformado dentro do útero materno), minha tese é de que os argumentos que justificam ou rejeitam o uso de embriões para pesquisa e a 
${ }^{1}$ Louis DUMONT, 1992 e 1997.

${ }^{2}$ DUMONT, 1992, p. 35.

${ }^{3}$ Naara LUNA, 2007.

${ }^{4}$ Letícia CESARINO, 2006. antecipação de parto de anencéfalo coincidem em vários pontos porque são tributários da mesma configuração de valores e se fundamentam na mesma figura de pessoa: o indivíduo como valor segundo Dumont. ${ }^{1}$ Esse indivíduo é o "ser moral, independente e autônomo, e por conseqüência essencialmente não social, que veicula os nossos valores supremos e ocupa o primeiro lugar de nossa ideologia moderna do homem e da sociedade". ${ }^{2}$ Nesse sentido, o núcleo da argumentação muitas vezes se articula com respeito a lhes negar ou atribuir a condição de seres humanos sujeitos de direitos.

Um texto anterior explora as descrições de caráter biológico empregadas no debate sobre o estatuto do embrião in vitro. ${ }^{3} \mathrm{O}$ presente artigo, além de acrescentar o anencéfalo como objeto, amplia seu enfoque para as estruturas de argumentação, referentes ou não à biologia, que fundamentam o debate sobre a condição de ambos os seres, em particular com respeito à atribuição do caráter de sujeito de direito. Selecionaram-se textos publicados na imprensa, a partir de levantamento sistemático no jornal O Globo, entre 2000 e 2005, e busca aleatória em outros jornais e periódicos de circulação nacional. A prioridade foram artigos da página de opinião, em que os autores na maioria não são profissionais do jornal, mas integram alguma categoria social que lhes confere autoridade para se pronunciarem sobre o assunto; as cartas dos leitores; um fórum mais democrático de representação, no qual mesmo notáveis se manifestam; e editoriais de jornal. Houve menção a um número reduzido de matérias propriamente jornalísticas.

A fim de investigar as representações sobre o embrião humano, o enfoque deu-se em textos que lidavam com o uso de embriões humanos como material de pesquisa, em particular para formar células-tronco. O período do levantamento antecede e ultrapassa um ciclo de eventos no Poder Legislativo referente à aprovação da nova Lei de Biossegurança, cujo anteprojeto foi encaminhado pelo Executivo ao Congresso em 31 de outubro de 2003, com tramitação até 24 de março de 2005 , além de uma ação de inconstitucionalidade em maio do mesmo ano. ${ }^{4}$ Também com respeito ao debate sobre anencefalia, identificou-se o ciclo de controvérsias entre 2002 e 2005. No caso da autorização da antecipação de parto de feto anencefálico, houve um ciclo marcado por diversos pleitos de interrupção de gestação, negados em alguma instância, que alcançaram repercussão na imprensa, além de uma liminar do Supremo Tribunal Federal (STF) autorizando a interrupção nesses casos, de acordo com ação proposta pela Confederação Nacional dos Trabalhadores na Saúde. A liminar foi parcialmente revogada menos de quatro meses 
${ }^{5}$ Maíra Costa FERNANDES, 2007.

${ }^{\circ}$ Marilyn STRATHERN, 1992.

${ }^{7}$ Victor Witter TURNER, 1957 depois. Aguarda-se a retomada do julgamento pelo Supremo Tribunal Federal. ${ }^{5}$

Marilyn Strathern apontou com respeito às novas tecnologias reprodutivas o surgimento de um novo ente legal e social: o embrião extracorporal criado por FIV. ${ }^{6}$ Não apenas o estatuto do embrião humano criado em laboratório tem sido objeto de debate, mas também a figura do feto anencefálico, conhecido como bebê sem cérebro, após debate jurídico por ora suspenso sobre a antecipação do parto quando há gestações de fetos com essa anomalia. A cobertura do debate sobre a nova Lei de Biossegurança na imprensa brasileira e do debate no Supremo Tribunal Federal sobre a autorização legal da antecipação do parto de feto anencefálico, ou interpretação da lei no sentido de ampliação dos permissivos para aborto legal, tem em comum o fato de os dois configurarem situações de drama social. ${ }^{7}$

Drama social é o conceito analítico para situações de crise que emergem periodicamente por meio das quais se podem ver as contradições escondidas e os conflitos em um sistema social. Conflitos representam um desafio a alguma norma que dirige o comportamento. No drama social, conflitos de interesses latentes se manifestam, o que ocorre em qualquer nível da organização social, e o drama e se desenrola até o desfecho em comportamento convencional atuado publicamente. A resolução jurídica com autorização das pesquisas e o fim das manifestações públicas de protesto representariam o desfecho no caso da autorização do uso de embriões humanos para pesquisa. ${ }^{8} \mathrm{Em}$ sociedades complexas, é nas instâncias jurídicas que se obtém a resolução ou o acordo, mesmo temporário e tenso, acerca de dramas e conflitos públicos, por isso ambos os temas têm sido objeto de debate jurídico e da produção analítica por parte da ciência do Direito. ${ }^{9}$

Reconhecendo que, em ambos os casos, se estruturou uma situação de drama social, o enfoque não está no desenrolar dos eventos, mas no tipo de argumentação utilizada por aqueles que se manifestam na imprensa. Antes é necessário analisar o processo histórico pelo qual são constituídos esses novos entes, começando pela autonomização do feto.

\section{A autonomização do feto}

Iniciando com a abordagem da história do debate sobre o aborto na Igreja Católica, é possível entender como se constitui ao longo dos anos o estatuto atribuído ao embrião humano. Segundo Jane Hurst, na literatura penitencial da Alta Idade Média, no Direito Canônico (primeira compilação em 1140 ) e na teologia, encontra-se a teoria da hominização posterior do feto, segundo a qual, antes da entrada da alma 
10 Jane HURST, 2000.

11 Wendy FYFE, 1991. racional, princípio atualizador da forma substancial, haveria apenas o potencial do corpo como matéria primeira. Havia penitências diferentes para o aborto, conforme realizado antes e depois da hominização, sendo tais punições associadas às regras contra fornicação. No século XVII, o médico Paolo Zacchia defende pela primeira vez $\mathrm{o}$ argumento de que a alma racional estaria presente desde a concepção. A despeito disso, a posição da Santa Sé se mantém a mesma até 1869. No século XIX, aparecem opiniões defendendo o embrião como vida potencial. Em 1864, o teólogo jesuíta Jean Gury afirma que o feto, mesmo sem receber a alma, caminha para a formação de um ser humano, logo, sua expulsão seria um homicídio. Em 1869, o Papa Pio IX declara o aborto como homicídio, o que é incluído no novo código de Direito Canônico de 1917. Apenas no século XX, afirma-se explicitamente o conceito de proteção do embrião desde a concepção, designado de "direito à vida", tendo por pressuposto a hominização imediata. ${ }^{10}$

A legislação sobre aborto se desenvolve com base em um raciocínio semelhante às mudanças na doutrina católica. Na Inglaterra, apenas em 1803 decretou-se uma lei que punia o abortamento exercido tanto antes como depois do quickening, isto é, da fase em que a mulher sente os movimentos fetais; as leis anteriores puniam apenas o ato posterior a tal fase. ${ }^{11}$ A despeito de se ampliar a definição do crime para abranger a gestação inteira, a punição para abortamentos anteriores ao quickening é bem mais branda do que para tentativas após esse período. Da mesma forma que a hominização com entrada da alma, isso indica uma visão gradualista de atribuição do estatuto de pessoa. Esse ponto fica bem claro na lei inglesa de 1929, que pune com maior severidade o aborto cometido a partir da $28^{a}$ semana, estabelecendo aí a viabilidade da "criança" (sic), a capacidade de sobreviver fora do útero. Wendy Fyfe identifica no desenvolvimento da legislação o processo de perda da definição e do controle da gestação por parte da mulher, bem como a separação explícita do feto em relação à gestante, quando o quickening deixa de ser a referência, substituído por noções médicas de viabilidade. Identifica-se o processo de autonomização do feto, tornado objeto do olhar médico independente da mãe, encarada como seu receptáculo.

A construção da disciplina acadêmica de embriologia também está relacionada à representação do feto como entidade autônoma e das mulheres como incubadoras passivas. Em pesquisa sobre a história da embriologia nos Estados Unidos entre 1910 até o fim da década de 20, Lynn Morgan conclui que as imagens veiculadas não resultaram na personificação do embrião 
12 Lynn MORGAN, 2003.

${ }^{13}$ Rosana Machin BARBOSA, 1999.

${ }^{14}$ Ruth Schwartz COWAN, 1992; e Ruth HUBBARD, 1990.

${ }^{15}$ Lilian Krakowski CHAZAN, 2007. nem influenciaram atitudes acerca do aborto, proibido em todo o país. Embriões e fetos coletados em abortamentos e dissecados serviam de matéria de argumentação para debates sobre influências no desenvolvimento pré-natal, teorias da evolução das espécies e corporificação de diferenças raciais. Os embriologistas tendiam a descobrir nos embriões exatamente os pontos para fundamentar suas opiniões prévias. ${ }^{12}$

Na segunda metade do século XX, a aplicação de técnicas de ultrassonografia para acompanhar o desenvolvimento da gestação é um dos desenvolvimentos mais relevantes, o que permitiu o acesso direto a imagens do feto reproduzidas em um monitor. Isso teria contribuído para a visão de autonomia do feto quanto ao corpo materno. ${ }^{13}$ Além da ultrassonografia obstétrica, um procedimento de diagnóstico fetal, entre as técnicas de testagem pré-natal, destacam-se a amniocentese e a biópsia de vilosidades coriônicas. ${ }^{14} \mathrm{~A}$ amniocentese difundiu-se desde a década de 70 nos Estados Unidos. As técnicas, se propiciam a autonomização do feto como paciente, podem ser apropriadas pelos usuários com outros sentidos. Em contexto brasileiro no início do século XXI, verifica-se que as sessões de ultrassom obstétrico ultrapassam a obtenção de diagnóstico clínico do feto, mas são ocasiões para pais e toda a família se ligarem ao "bebê" que está por vir, sendo o feto dotado de subjetividade sob diversos aspectos, a partir de sua corporeidade e movimentos. ${ }^{15}$

Sarah Franklin afirma que os grupos antiaborto na Inglaterra afastaram-se da retórica de que toda vida humana seria sagrada porque fora criada por Deus, substituindo definições religiosas da vida por definições biológicas. Assim, a condição de pessoa do feto não estaria mais na presença da alma, mas na posse de um corpo e um genótipo humanos. Constitui-se o feto como agente individual separado da própria mãe. Essa imagem do feto isolado é construída por tecnologias visuais (câmeras no interior do útero, ultrassonografia), definindo-se sua condição de pessoa de modo associal, a partir de fatos naturais. A construção do feto como pessoa potencial e individual se vale de um raciocínio teleológico, baseando-se em conceitos de força vital biológica e de determinismo genético, de modo que, no momento da concepção, seu curso de vida já estaria mapeado geneticamente. A individualidade do feto mostrase no conceito de viabilidade. Assim, a biologia torna-se a base para a construção cultural de categorias sociais. ${ }^{16} \mathrm{~A}$ fertilização in vitro, ao propiciar a formação de embriões humanos fora do corpo em laboratório, representa o auge do processo de autonomização do feto, figura formada independentemente do corpo materno mediante intervenção médica. 
${ }^{17}$ Ondina Fachel LEAL e Bernardo LEWGOY, 1995.

${ }^{18}$ Sobre a condição do embrião humano na doutrina católica recente, ver LUNA, 2002.

19 Marjorie Reiley MAGUIRE apud Maureen JUNKER-KENNY, 1998, p. 63.

${ }^{20}$ LEAL e LEWGOY, 1995.

\footnotetext{
${ }^{21}$ A linha primitiva constitui o primórdio da medula espinhal e representa um marco de individualização do embrião, tema que será discutido adiante (Tania SALEM, 1997; e STRATHERN, 1992). 22 Fenella CANNELL, 1990; e SALEM, 1997.
}

Ondina Fachel Leal e Bernardo Lewgoy verificaram diferentes tipos de ontologias referentes à condição de pessoa do embrião humano, empregadas no debate sobre o aborto. ${ }^{17} \mathrm{~A}$ ontologia substancialista baseia a proteção do embrião no critério biológico de presença da pessoa humana desde a concepção. Na versão religiosa mais antiga dessa ontologia, a alma passa a existir a partir daí. ${ }^{18}$ Uma versão laica dessa ontologia substancialista identifica o estatuto jurídico de pessoa humana no esboço genético do indivíduo contido no seu genoma. Há também uma ontologia relacional em que a garantia de direitos a seres humanos incompletos depende do arbítrio da comunidade, faltando ao embrião o atributo da racionalidade. Uma variação dessa ontologia relacional está na reflexão feminista sobre estatuto de pessoa do embrião, proposta pela teóloga feminista Marjorie Reiley Maguire. Segundo Maguire, o estatuto de pessoa do embrião começa quando a "mãe faz uma aliança de amor com a vida em desenvolvimento dentro dela para levá-la ao nascimento". ${ }^{19}$

A teóloga defende que a eliminação ou experimentação nos "óvulos fecundados" não seria imoral, pois "não há pessoas flutuando em tubos de ensaio". A socialidade seria $\mathrm{o}$ aspecto fundamental da condição de pessoa, e o lado biológico não basta para garantir esse estatuto. Com respeito a práticas abortivas das mulheres das camadas populares brasileiras, segundo Leal e Lewgoy, se há um princípio de condenação do ato como pecado ou crime com base na versão religiosa (especificamente católica) dessa ontologia de pessoa, por outro lado, o não reconhecimento do atraso menstrual como gravidez opera como estratégia ao se negar a existência de um embrião. Essa abordagem relacional abriria espaço para o uso de chás ou medicamentos abortivos. ${ }^{20}$

Se o debate sobre a condição de pessoa do embrião se origina em discussões anteriores sobre a licitude do aborto, as novas tecnologias reprodutivas levantam a questão a partir de outros ângulos, em função das possibilidades crescentes de intervenção em embriões criados em laboratório. O conceito de pré-embriáo, designando a fase anterior ao surgimento da linha primitiva, abre espaço para a experimentação com esses embriões até o $14^{\circ}$ dia após a fertilização, um interesse da comunidade científica britânica. ${ }^{21}$ Um comitê interdisciplinar em fertilização e embriologia humanas instituído pelo governo do Reino Unido, em 1982, elaborou o Relatório Warnock a fim de criar parâmetros para o estabelecimento de políticas públicas e a legislação britânica sobre a reprodução assistida, e a possibilidade de experimentação com embriões. ${ }^{22}$ As recomendações do relatório são referência na discussão 
${ }^{23}$ Michael MULKAY, 1997.

${ }^{24}$ STRATHERN, 1992.

${ }^{25}$ Luc BOLTANSKI, 2004.

${ }^{26}$ BOLTANSKI, 2004.

27 MORGAN, 2003. envolvendo as tecnologias reprodutivas e o estatuto do embrião. Após a publicação desse relatório, a embriologista do comitê sugeriu o termo "pré-embrião" para designar essa fase inicial. ${ }^{23}$ Noções de individualidade do feto mostramse no conceito de viabilidade e na distinção entre embrião e pré-embrião.

O conceito de pré-embrião sugere uma noção gradualista de pessoa. Nas noções essencialistas da emergência da condição de pessoa, o episódio da concepção é o marco de início, enquanto em noções gradualistas o atributo de pessoa se instala ao longo do desenvolvimento. Segundo Strathern, ${ }^{24}$ essas posições se baseiam em uma visão evolucionista do tempo, identificada com o que chamo de posição gradualista, e uma visão episódica do tempo, representando o início radical, o que constitui a visão que designo essencialista.

Segundo Luc Boltanski, os meios tecnológicos, como as técnicas de reprodução assistida e os dispositivos jurídicos orientados à defesa da obtenção do filho como projeto, criam novas categorias muitas vezes inclassificáveis, quando se estabelecem direitos do feto dentro do útero ou se propõem cirurgias fetais. Define-se a categoria de tecnofeto a partir desse desenvolvimento tecnológico, exemplificado na formação de embriões congelados restantes da fertilização in vitro. A tentativa de esboçar um estatuto legal, a partir da atribuição de dignidade ao embrião fora do corpo, levanta a questão das fronteiras da humanidade. O tecnofeto desestabiliza a distinção nítida entre o feto autêntico ("dirigido a virar bebê") e o feto tumoral ("devolvido ao nada"). A visualização dos fetos também coloca em risco a distinção entre feto autêntico e feto tumoral, nos exemplos do uso de fotografias de fetos usadas pelos grupos antiaborto e das tecnologias de imagem que 0 mostram no útero. As tecnologias que tornaram o feto acessível aos sentidos e os conflitos envolvendo o feto permitiram sua entrada na sociedade. O acesso do feto ao mundo social se contrapõe à necessidade de fazê-lo desaparecer com a legalização do aborto. ${ }^{25}$

Boltanski comenta sobre abordagens desconstrucionistas que contestam a crença na existência de um feto em si dotado de atributos permanentes e mostram-no como um ser histórico e social. ${ }^{26} \mathrm{Um}$ exemplo está em Morgan, ao afirmar que os significados atribuídos a imagens variam de acordo com o contexto em que são visualizadas. Os embriões em si não colocam dilemas, mas as controvérsias sociais fornecem as lentes interpretativas por meio das quais embriões são dotados de sentido. ${ }^{27}$ 
28 LUNA, 2001.

${ }^{29}$ Volnei GARRAFA, 2001 , p. 50.

\section{O estatuto dos embriões humanos extracorporais e a pesquisa com células-tronco}

Que sentidos são atribuídos à possibilidade do uso de embriões humanos em pesquisa? Para se acompanhar a sucessão dos argumentos no debate que configura um drama social, apresentam-se os textos de jornal em ordem cronológica. No princípio, o debate sobre as investigações nesses embriões estava englobado no debate sobre a clonagem humana. Opunha-se à clonagem ruim, à reprodutiva, em que se transfere o "embrião clonado" para o útero no intuito da geração de bebês-cópias, e à terapêutica, quando a técnica seria utilizada na produção de tecidos para a doação a partir de embriões. ${ }^{28}$

Nesse contexto está a declaração de Volnei Garrafa, ${ }^{29}$ então presidente da Sociedade Brasileira de Bioética, apoiando o uso de células-tronco de embriões "para salvar ou melhorar a vida das pessoas". Garrafa continua: "o status moral de um indivíduo adulto e doente não pode ser comparado ao de um aglomerado de células que não pensa, não adquiriu nem forma nem função". Ele responde negativamente à pergunta se embrião é pessoa e afirma a impossibilidade de se afirmar com precisão "o momento exato quando isso se dá" (a emergência da condição de pessoa). Segundo Garrafa, essa "questão não é técnica; é moral". O estatuto do embrião como aglomerado de células é comparado desfavoravelmente ao do indivíduo adulto e doente. O primeiro não tem forma nem função definidas, isto é, em sua indiferenciação falta-lhe a individualidade, além disso, não pensa, carecendo de racionalidade. Está-se diante de uma definição gradualista da emergência da condição de pessoa: em certa etapa do desenvolvimento surge a condição. Os valores da pessoa humana referemse a sua diferenciação e individualidade, e a sua autoconsciência e racionalidade. O geneticista Sergio Danilo Pena, em entrevista, contesta a noção de início da vida na fecundação: "acho errada e um pouco nociva a idéia de que a partir do momento em que um espermatozóide entra num óvulo já se tem um ser humano. O que existe é o potencial para um ser humano. Estamos falando de um aglomerado de células". Pena recomenda cautela quanto ao uso do argumento vida: "um espermatozóide é uma célula que tem vida". Por esse raciocínio, uma ejaculação resultaria na morte de milhões de vidas. ${ }^{30}$

Um leitor reage: Nicolau da Rocha Cavalcanti afirma que: "há muito já se provou que desde a concepção até a morte de um ser humano não há mudança substancial, não 
${ }^{31}$ Nicolau da Rocha CAVALCANTI, 2001 , p. 6.

${ }^{32}$ Enio Porto DUARTE, 2001, p. 6.

${ }^{33}$ LUNA, 2002.

${ }^{34}$ Catherine WALDBY, 2002.

${ }^{35}$ BUSH..., 2002, p. 6.
${ }^{36}$ Marcos Paulo Castilho COSTA, 2004, p. 6. O autor comete um pequeno equívoco, pois em cada gameta há um conjunto de 22 cromossomos acrescido do cromossomo sexual ( $X$ ou $Y$ ) e, em cada célula somática, há, portanto, 23 pares de cromossomos. se podendo afirmar que o embrião não é uma pessoa". Acusa Volnei Garrafa de usar a mesma fundamentação dos séculos XV e XVI "para sustentar que negros e índios não eram seres humanos". ${ }^{31}$ O leitor apresenta uma visão inaugural e essencialista da pessoa humana, que se iniciaria na fecundação. Cavalcanti reconhece que a atribuição da condição de pessoa variou historicamente, o que é alvo de críticas. Já o leitor Enio Porto Duarte argumenta a partir de valores religiosos: "existe algo intocável no homem atual, que é o seu sentido de vida, relacionado com aquilo que não passa, o transcendental". ${ }^{32}$ A argumentação a partir de questões religiosas ou metafísicas é minoritária nos textos examinados. Mesmo autoridades religiosas se respaldam nos conceitos biológicos. ${ }^{33}$ Há tensão entre o valor da vida do embrião, identificada como biografia pelos opositores a seu uso em pesquisa, e as perspectivas dos cientistas, que veem nas células vitalidade biológica. ${ }^{34}$

O editorial do jornal $O$ Globo critica a posição do presidente dos EUA, George W. Bush, defensor da proibição geral da clonagem com a justificativa de que "nenhuma vida humana deve ser explorada ou extinta em benefício de outra". ${ }^{35}$ Essa posição vedaria o uso de embriões humanos para a obtenção de células-tronco. O editorial apresenta a discordância de

considerar vida humana aglomerados embriônicos criados para a obtenção de células-tronco, do tamanho da espessura de um fio de cabelo, e que ainda não tenham desenvolvido características que, por qualquer critério razoável, possam ser consideradas definidoras de um ser humano.

Esse texto frisa o grau de desorganização e indiferenciação dos embriões representado na falta de características "definidoras de um ser humano".

Uma definição genetizante do estatuto do zigoto e do clone vem na carta do leitor Marcos Paulo Castilho Costa. ${ }^{36}$ Ele define óvulo e espermatozoide por terem 22 cromossomos cada um (sic), enquanto após a fecundação "forma-se uma célula chamada zigoto, que possui os 44 cromossomos" (sic). Na clonagem "de uma célula do nosso corpo", "são extraídos os 44 cromossomos que serão inseridos no óvulo vazio" (o óvulo sem núcleo). Esse "zigoto" formado "terá as características apenas do doador, sendo, portanto, uma cópia exata, um gêmeo univitelino com idade diferente". Por fim, Costa se pergunta: "onde está a criação da vida?". Esse leitor questionava haver "criação da vida" na clonagem. Dois leitores reagem. Everton N. Jobim assegura haver "uma recriação da vida a partir da deliberada intervenção num processo natural, estabelecendo uma via de duplica- 
${ }^{37}$ Everton N. JOBIM, 2002, p. 6.

${ }^{38}$ Antônio Carlos de Oliveira LAUS, 2002, p. 6.

${ }^{39}$ Eloi S. GARCIA, 2003, p. 7.

40 BOLTANSKI, 2004.

${ }^{41}$ Beth A. CONKLIN e Lynn Marie MORGAN, 1996. ção de indivíduos. [...] Cria-se, de fato, a possibilidade de produzir vida, mas sempre recorrendo a matérias orgânicas preexistentes" ${ }^{37}$ Antônio Carlos de Oliveira Laus alerta que a crítica ao processo de clonagem refere-se à "imoralidade do ato" e rebate a comparação com a geração de gêmeo univitelino: "a geração de um gêmeo dá-se naturalmente, a partir do material genético paterno e materno, no seio materno, que tem a função biológica de guardá-lo e alimentá-lo, sem mais nada acrescentar à essência desses pequenos seres, que são humanos desde a concepção". ${ }^{38}$ Nas menções a "matérias orgânicas preexistentes" que produzem a vida ou "material genético materno e paterno", verifica-se a noção de que a biologia define o ser. Na carta de Laus é evidente sua posição essencialista da condição humana na afirmativa de que o seio materno "mais nada acrescenta à essência desses pequenos seres, que são humanos desde a concepção".

Eloi S. Garcia, pesquisador da Fiocruz e seu expresidente, em artigo sobre a clonagem humana e de animais, lança a pergunta crucial: "quando a vida humana começa? Quando um punhado de células sem o menor vestígio de sistema nervoso, em uma placa de Petri no laboratório, merece a proteção legal da sociedade?". ${ }^{39}$ Ao contrário das posições acima, o último autor questiona que o processo de clonagem produza cópias de pessoas: "pela clonagem estará sendo criada uma cópia genômica e não da pessoa que doa o núcleo celular". Garcia aponta a questão-chave do debate sobre qualquer intervenção em embriões e fetos humanos: o início da vida. Outra questão associada é desde quando a sociedade irá proteger os seres reconhecidos como humanos, ponto também abordado por Boltanski. ${ }^{40} \mathrm{Em}$ abordagens comparativas da etnologia, constata-se que a resposta não é evidente, pois o reconhecimento da condição de pessoa de um bebê recém-nascido não é automático, por sua essência humana, mas depende de sua rede de relações. ${ }^{41}$ Ao descrever o embrião como "um punhado de células" "sem sistema nervoso" e situado no contexto de laboratório, Garcia aponta para as ausências que o cercam: um ser de pequena escala, desorganizado ou indiferenciado, ou seja, carente de individualização, desprovido também do sistema nervoso que define a capacidade racional e de autoconsciência humana, por fim, situado em meio onde seu desenvolvimento é impossível - o laboratório em lugar do útero. Trata-se de um embrião inviável fora da relação com a mãe. Sua descrição do embrião extracorporal nega-lhe as características de pessoa humana, ou do indivíduo, figura de pessoa no Ocidente conforme Dumont. Com enfoque genético, Garcia define o processo de clonagem não como cópia de pessoas 
42 José Ebrienos ASSAD, 2003, p. 7.

${ }^{43}$ NOSSA OPINIÃO..., 2003, p. 6.

${ }^{44}$ Eliane AZEVEDO, 2003, p. 6. A professora participa do grupo de assessoria em questões de bioética da CNBB, ver CNBB..., 2007.

${ }^{45}$ Herbert PRAXEDES, 2003, p. 6. O médico e professor da UFF foi palestrante no seminário "Vida: o primeiro direito da cidadania", promovido pela Pastoral Universitária do Regional Leste 1 da CNBB, em julho de 2005 (CONFERÊNCIA NACIONAL DOS BISPOS DO BRASIL, 2005).

${ }^{46}$ CLONAGEM..., 2004, p. A2. ou seres, mas como cópia genômica: a transcrição do DNA do núcleo. O autor retoma a questão do Direito, invocando a responsabilidade da sociedade na proteção legal de seres. É distinta a proteção devida ao ser humano e ao material biológico disponível, conforme a sociedade os defina.

Outro artigo propondo a clonagem terapêutica, de autoria de José Ebrienos Assad, ex-secretário de Saúde do município do Rio de Janeiro, discute as diferenças conceituais quanto ao embrião humano ser vida ou potencial de vida. ${ }^{42}$ Lembra que o embrião é "um conjunto de dezenas de células sem forma, sendo que dez por cento apenas deverão vingar no útero de uma mulher e, se forem resfriadas, este percentual cai para três por cento". A partir da pequena probabilidade de o embrião extracorporal resultar em gravidez (10\%), reduzida a $3 \%$ em se tratando de embrióes criopreservados, o autor defende o emprego de células-tronco embrionárias. Trata-se do tema da viabilidade. Seguindo essa linha, novo editorial de $O$ Globo, discutindo o tema "embriões e ética", considera obscurantista e cruel proibir a investigação científica com embriões rejeitados. ${ }^{43}$

Em resposta ao editorial, representando outra opinião, Eliane Azevedo, professora titular de bioética na Universidade Estadual de Feira de Santana, discorre sobre documentos internacionais de direitos humanos que estabelecem a proteção de pessoas sujeitos de pesquisa. Considerando que "o limite da pesquisa em seres humanos seja a dignidade humana", o uso de embriões humanos em experimentação seria "um meio sem fins que o justifiquem". Defende que o "respeito à vida humana deve ser absoluto", pois "a pessoa humana no embrião é uma potencialidade, não uma probabilidade". ${ }^{44}$ Azevedo assume postura de caráter religioso ao afirmar a dignidade da pessoa humana como valor absoluto e atribuir a condição de pessoa ao embrião uma representação essencialista. O leitor Herbert Praxedes toma posição semelhante e recorda que "desde que foram divulgadas as primeiras experiências com bebês de proveta a Igreja Católica se posicionou contra esse tipo de ação", em "defesa da dignidade e do ser humano, mesmo que ainda embrião" ${ }^{45}$ Afirma não haver "dúvidas científicas que o embrião tem vida, ainda que em seu estágio inicial, mas mesmo assim, digna de respeito", por isso não pode ser objeto de pesquisas, mesmo com finalidade terapêutica.

O editorial da Folha de S. Paulo de junho de 2004 está no contexto dos debates sobre a Lei de Biossegurança no Senado. ${ }^{46}$ O projeto autoriza o uso de "embriões - na verdade blastocistos, isto é, emaranhados de uma centena de células - que sobraram de tratamentos de fertilização e que nunca seriam implantados num útero para originar uma gravidez". O editorial considera que os valores do "lobby 
${ }^{47}$ Lygia Veiga PEREIRA, 2004, p. 7.

${ }^{48}$ Maria do Carmo de Souza RODRIGUES, 2004, p. 6. evangélico-católico" não devem "ditar as regras de uma República pluralista, laica e que valoriza a vida efetiva, atual, mais do que a mera possibilidade de vida contida num blastocisto". Sublinha também que o blastocisto se encontra no tubo de ensaio, e não na trompa ou útero, portanto, sem possibilidade de dar origem a um feto. $O$ artigo, além de apontar um dos grupos que polarizam o debate, distingue a vida efetiva e atual de possíveis beneficiados do potencial de vida que não se realizará caso os "blastocistos" continuem em criopreservação. Além do meio, mais uma vez se considera a forma: "emaranhados de uma centena de células" chamados de blastocistos. 0 uso do termo "blastocisto", em lugar de "embrião", é um artifício retórico para desvincular a associação de embrião com vida e com pessoa. Na rotina das clínicas de fertilização, a criopreservação de embriões se faz no estágio anterior de mórula, portanto, apenas após o descongelamento e o cultivo haverá formação de blastocistos para deles se extraírem as células-tronco.

No mesmo contexto, está o artigo de Lygia Veiga Pereira, professora e pesquisadora do Departamento de Biologia do Instituto de Biociências da USP, revelando sua preocupação com o posicionamento da CNBB, que solicita aos políticos a manutenção da proibição da "produção de embriões humanos destinados a servir como material biológico disponível" ${ }^{47}$ Ela contrapõe a visão desses religiosos, que veem no uso de um embrião humano a destruição de uma vida, e a posição dos cientistas, que veem como oportunidade de salvar vidas. Mais uma vez se menciona que o embrião não está implantado no útero materno e seu caráter indiferenciado: "um conglomerado amorfo de 100 a 200 células". Ressalta que alguns desses embriões são defeituosos e não conseguiriam se desenvolver em um bebê. Aos embriões faltam forma, individualidade, perfeição e viabilidade - tanto em função de sua qualidade, como por estarem fora do útero materno - para designá-los de vidas ou pessoas. O caráter incompleto e de projeto inviável em função de não se fazer a transferência para o útero nega a condição de pessoa do embrião humano.

O artigo de Maria do Carmo de Souza Rodrigues é centrado no tema do estatuto do embrião humano. ${ }^{48}$ A autora, médica geneticista clínica do Instituto Fernandes Figueira, Fiocruz/RJ e membro da Associação dos Médicos Católicos do Rio de Janeiro, aponta a alternativa do uso de células-tronco adultas, questionando "a insistência em sacrificar vidas de embriões humanos". Segundo Rodrigues, "Cientificamente, não há como contestar que a vida humana começa no momento da fecundação, quando é desencadeada uma série de eventos em cascata envolvendo os 
49 Marco Aurélio Gonçalves FERREIRA, 2004, p. 6.

50 Stevens REHEN e Alysson MUOTRI, 2005, p. 7.

${ }^{51}$ Cristiane MELO, 2005, p. 7. genes do desenvolvimento levando ao desenvolvimento do embrião até o nascimento". A autora conclui que "a célulaovo resultante é uma vida humana e o embrião humano é ser humano que possui dignidade de ser humano, possui todos os direitos humanos decorrentes do fundamental direito à vida". A médica católica defende o valor da dignidade humana e considera os embriões detentores de direitos.

Posição oposta vem na carta do leitor Marco Aurélio Gonçalves Ferreira, que questiona "o discurso" que privilegia "embriões, em detrimento de indivíduos já devidamente formados, com consciência e vida plena". ${ }^{49}$ O autor sugere o debate sobre "o verdadeiro início da vida" e quando se "adquire o status de ser humano", lembrando que os conceitos de ser humano e dignidade humana são oriundos da cultura. O artigo de Stevens Rehen (professor da UFRJ e pesquisador do Scripps Research Institute, da Califórnia) e de Alysson Muotri (pesquisador do Salk Institute, da Califórnia) retoma o argumento da forma do embrião, esclarecendo que células-tronco usadas em pesquisa não são derivadas de fetos, mas de "conjuntos celulares muito pouco desenvolvidos, congelados em clínicas de fertilização e eventualmente descartados". ${ }^{50}$ Relatam que, em evento nos EUA para debate da pesquisa com células-tronco, reunindo a comunidade científica, filósofos, economistas e representantes de diversas comunidades religiosas, os representantes judeus e muçulmanos foram favoráveis à pesquisa, e apenas entre os cristãos não houve consenso. Essa observação rompe com o estereótipo repetido nos artigos, que opõe religião e ciência, mostrando divergências dentro da comunidade científica e dos grupos religiosos.

Quanto à oposição de religião e ciência, os autores mais identificados com valores do campo religioso geralmente iniciam a argumentação afirmando a base científica de suas posições. O artigo de Cristiane Melo, professora da Pontifícia Universidade Católica de São Paulo, declara que "estudos embriológicos contemporâneos afirmam, sem qualquer dúvida, que o princípio da vida humana coincide com o da fecundação". ${ }^{51}$ A autora defende que ocorrendo a "fecundação de um ser humano, seja embrião ou não, [este] deve ter reafirmado seu direito natural à vida". Melo alega que não se deve tratar pessoas como coisas, o que ocorre "quando os embrióes congelados não alcançam êxito, ou seja, não adquirem o status de pessoas, para serem, então, coisas a serem destruídas ou relegadas à obtenção de células-tronco, transformando-se em cobaias de laboratório". Com respeito à questão jurídica, a autora assevera que o embrião já possui a garantia de inviolabilidade do direito à vida, prevista na Constituição, pois essa "garantia não teria sentido se não alcançasse todas as fases da vida 
52 Luiz Fernando Dias DUARTE, 1999.

${ }^{53}$ FERNANDES, 2007.

54 FEDERAÇÃO BRASILEIRA DAS ASSOCIAÇỖES DE GINECOLOGIA E OBSTETRÍCIA apud FERNANDES, 2007.

55 PINOTTI apud Maria Lúcia Fernandes PENNA, 2005. humana, que começa na concepção e vai até a morte da pessoa". Melo atinge o cerne da questão: o embrião é um ser humano possuidor de direitos ou é um objeto? Como atribui a esse ente a condição de pessoa, ela qualifica o processo de obtenção de células-tronco de transformar os embriões em cobaias. É necessário objetar que o termo "cobaia" não se aplica a entes microscópicos, mas a animais complexos com forma definida.

Paralelamente à controvérsia sobre o uso de embriões humanos em pesquisa, ocorria o debate na imprensa sobre a possibilidade de autorização legal para a antecipação de parto de anencéfalo ou interrupção voluntária de gravidez em caso de anencefalia.

\section{O feto anencefálico: questões sobre vida e pessoa}

Se a discussão sobre o estatuto do embrião gerado por fertilização in vitro e a possibilidade de seu uso como material de pesquisa esbarra em questionamentos quanto à sua inviabilidade em função do meio (embrião no laboratório, e não no útero da mulher), no caso do feto anencefálico, a inviabilidade seria decorrente de sua condição biológica, e não de sua inserção em outro ambiente mais favorável. Existe aqui um julgamento sobre a perfectibilidade da condição humana. A perfectibilidade é o valor de origem iluminista segundo o qual a espécie humana seria dotada da capacidade de se aperfeiçoar indefinidamente. ${ }^{52} \mathrm{Em}$ ambos os seres faltam atributos considerados essenciais. Se, no primeiro caso, o aproveitamento do embrião em pesquisas e sua consequente destruição seriam justificados pela possibilidade de benefícios a pessoas doentes, recuperando saúde de outros, no segundo caso, o argumento é a redução do sofrimento da gestante, ciente da condição física do feto que porta.

Anencefalia é uma malformação fetal incompatível com a vida. A anomalia ocorre por falha na formação do tubo neural, resultando na ausência da maior porção do cérebro, crânio e couro cabeludo, de modo que a parte remanescente é sempre exposta, sem cobertura de ossos ou pele. ${ }^{53}$ Segundo dados da Federação Brasileira das Associações de Ginecologia e Obstetrícia (FEBRASGO), ocorre um caso a cada 1.600 nascidos vivos, e nascem com vida entre 2,7 a 3 milhões por ano no Brasil. ${ }^{54}$ Conforme Pinotti, ${ }^{55}$ são 18 casos para cada dez mil nascidos vivos.

Defendendo a interrupção da gravidez em casos de anencefalia fetal, Penna pretende esclarecer a distinção entre os critérios de morte cerebral e o conceito de morte neurológica. Os oponentes ao aborto de anencéfalo argu- 
${ }^{56}$ PENNA, 2005.

57 FERNANDES, 2007.

${ }^{58}$ Rolland GIANOTTI, 2003.

59 A descrição dos detalhes dos procedimentos jurídicos é feita em FERNANDES, 2007. mentam que, devido à presença do tronco encefálico nesse feto, não se pode falar em morte cerebral. No debate ético, muitas vezes confunde-se o critério (morte de parte do encéfalo ou de todo ele) com o conceito de morte cerebral. Para demonstrar a diferença, Penna usa o exemplo da morte cerebral como evento que permite a retirada dos órgãos de uma pessoa considerada, a partir de então, um doador morto. Nesse caso, o conceito de biologicamente ativo serve para resolver a contradição entre pessoa morta e organismo vivo. A autora defende o conceito de morte neurológica no sentido de morte da pessoa: a impossibilidade de consciência. ${ }^{56} \mathrm{Na}$ anencefalia, há ausência física de formação cerebral que permita a consciência. Observa que o Conselho Federal de Medicina (CFM) autoriza a doação de órgãos do natimorto anencéfalo, na compreensão de constituir um natimorto cerebral. Nada mudou quanto à possibilidade de consciência entre a $12^{a}$ semana, quando se faz o diagnóstico por ultrassonografia, até o parto a termo: entende-se que o embrião ou feto está morto. Penna afirma que a conduta diante do feto morto é sua retirada do útero. Autores da área do Direito também compartilham essa opinião: não há que se proteger o bem da vida no caso do anencéfalo, pois não há pessoa viva. ${ }^{57}$

O debate sobre a autorização legal da antecipação do parto de feto anencefálico, ou interpretação da lei no sentido de ampliação dos permissivos para aborto legal (existente no Brasil somente nos casos de estupro e risco de vida da gestante), alcançou grande repercussão na imprensa brasileira entre os anos de 2003 e 2005. No final de 2002, diagnosticou-se a condição de anencefalia do feto de certa gestante ${ }^{58}$ Esta recebeu a recomendação pela comissão de ética médica do Instituto Fernandes Figueira da Fiocruz de interrupção da gestação. O pedido foi negado pela Justiça Criminal, cuja decisão se manteve mesmo após o recurso. Nos anos sob exame, esse foi o primeiro de uma sequência de casos noticiados pela imprensa, alguns dos quais envolvendo decisões em que a instância superior da Justiça revogava a decisão anterior. $O$ debate chegou ao Supremo Tribunal Federal, com a primeira ação sobre feto anencefálico a alcançar essa instância em 2004. ${ }^{59}$ Poucos meses depois, a Confederação Nacional dos Trabalhadores na Saúde propôs a arguição de descumprimento de preceito fundamental, que asseguraria às gestantes de anencéfalos o direito de se submeterem à interrupção de gravidez. $O$ ministro Marco Aurélio Mello deferiu uma medida liminar, em $1^{\circ}$ julho de 2004, que permitia a antecipação terapêutica do parto quando atestada a anencefalia por médico habilitado. Tal liminar foi revogada em sessão plenária três meses depois, e a ação aguarda decisão definitiva do plenário. 
${ }^{60}$ Dom Eugênio SALES, 2004, p. 7.

${ }^{61}$ BARROSO, 2004, p. 7.
Neste artigo, não se abordará o desenrolar de cada caso em que se solicitou à Justiça a interrupção da gravidez de anencéfalo, mas se analisarão exemplos em textos das páginas de opinião e cartas dos leitores que argumentam sobre a condição de pessoa do feto a fim de contrastar com as representações examinadas acima sobre o embrião.

Poucos dias depois do deferimento da liminar permitindo a antecipação do parto, Dom Eugênio Sales, cardeal arcebispo emérito da arquidiocese do Rio de Janeiro, escreveu um artigo de denúncia dos momentos difíceis da família cristã no Brasil, citando o aborto como ponto que se opõe "ao que Deus estabeleceu e Cristo ensinou".60 Menciona uma gestante que desistiu do pedido de autorização de aborto, "pois a morte tem que chegar na vontade divina". Em seguida, justifica sua posição teologicamente: "a sacralidade da vida humana deve ser cuidadosamente preservada e independe de credo religioso, pois integra a lei natural inscrita no coração de cada ser, criado à imagem de Deus". A aceitação do aborto seria sinal do enfraque-cimento do respeito absoluto à vida humana. Alerta os católicos para que na proximidade das eleições municipais não votem em candidatos favoráveis "ao crime de aborto, à interrupção de gravidez de fetos anencéfalos (sic), ao projeto de biossegurança com temas referentes à bioética". Refere-se aqui à autorização da pesquisa com embriões humanos pela Lei de Biossegurança. Por fim, afirma que o "Tribunal de Deus" está acima "do tribunal dos homens". O texto do cardeal é raro exemplo de argumentação direta em termos religiosos, sem apelo a dados da biologia. A "lei natural" também seria criação divina. A vida humana é valor meta-físico e transcendente. O feto é identificado com a vida sagrada e dotado da condição humana.

Se a argumentação repete os termos do debate sobre o estatuto do embrião humano, introduz-se o conflito dos direitos de gestante e feto, ponto ausente no caso do embrião extracorporal pelo motivo óbvio de ali não se configurar gestação. O advogado Luís Roberto Barroso comenta a decisão do Supremo Tribunal Federal de revogar a medida liminar que autorizava a antecipação do parto de anencéfalo com base na interpretação de que tal matéria não devia ser deliberada por medida liminar. ${ }^{61}$ Ele descreve detalhadamente a condição física do feto anencefálico (ausência de córtex e de hemisférios cerebrais) e enfatiza a impossibilidade de vida extrauterina. Defende a oportunidade de abreviar o sofrimento da mãe que não queira esperar até o parto. Seu argumento mais forte é que "o feto anencefálico, tragicamente, sequer chega a ter vida cerebral". Mesmo admitindo o respeito aos pontos de vista de "setores religiosos influentes", considera que "ciência, religião e Estado não compõem uma boa mistura". 
${ }^{62}$ Rafael Leite GUIMARÃES, 2004, p. 6.

${ }^{63}$ PRAXEDES, 2004, p. 6.

${ }^{64}$ Sérgio Bezerra de MATOS, 2004, p. 6.

${ }^{65}$ Fernando Cesar Magalhães REIS, 2004, p. 6.
Vários leitores reagem à declaração no artigo do advogado Luís Roberto Barroso de que a vida termina no momento da morte cerebral, pois essa constatação levaria à conclusão da inexistência de vida no feto anencefálico. O leitor Rafael Leite Guimarães diferencia morte cerebral de morte encefálica. ${ }^{62} \mathrm{~A}$ última seria o critério para a certeza da morte e consiste na "ausência total de atividades metabólica e elétrica no tronco cerebral", a parte do encéfalo que "contém os centros controladores da respiração e batimentos cardíacos". Apenas com essa parada irreversível pode haver remoção de órgãos para transplantes. O leitor Herbert Praxedes leva adiante esse raciocínio, argumentando que, segundo a Resolução $n^{\circ} 1.480 / 97$ do Conselho Federal de Medicina, a morte cerebral deveria ser chamada de morte encefálica. ${ }^{63} \mathrm{O}$ médico a constata com base em "coma aperceptivo, ausência de atividade motora supra-espinhal e apnéia". Contestando a afirmativa de Luís Roberto Barroso de que o anencefálico sequer chega a ter vida cerebral, Praxedes diz que o feto tem vida encefálica, ou seja, a prova que seu tronco encefálico está vivo é ele se movimentar, ter batimentos cardíacos, deglutir, urinar e evacuar. $O$ anencéfalo tem vida humana, como prova seu genoma, vida resguardada pela Constituição. Eis novamente a argumentação do direito à vida. Por fim, um terceiro leitor, Sérgio Bezerra de Matos, contesta Herbert Praxedes e defende Luís Roberto Barroso, alertando que o Conselho Federal de Medicina, ao reconhecer que a Resolução n 1.480/97 não alcançava os fetos com anencefalia, emitiu a Resolução ${ }^{\circ}$ 1.752 em 2004. ${ }^{64}$ Nesta se afirma que anencéfalos são natimortos cerebrais, o que corrige "argumentos de quem os considera nascituros após a constatação da anomalia". Uma posição semelhante, mas fundamentada no Direito, vem na carta de Fernando Cesar Magalhães Reis. Considera o "aspecto técnico" de que não se deverá punir o aborto "quando faltar o objeto material": "se não há vida ativa cerebral desde a concepção", não se pode falar em vida sob o aspecto jurídico. ${ }^{65}$ Guimarães e Praxedes, segundo a análise de Penna, confundem os critérios físicos de morte cerebral e o conceito. Guimarães compara a condição do anencéfalo à situação de pessoas que não são consideradas mortas e cujos órgãos não são disponíveis para transplante, por se constatar a atividade do tronco encefálico com a presença das funções vitais de respiração e batimento cardíacos. Praxedes explicita sua posição pela defesa do direito à vida do anencéfalo, afirmando que, além das funções vitais, o genoma humano prova a existência de vida humana. No genoma estaria a essência da vida e da condição humana. Matos, apoiado em resolução mais recente do CFM e usando argumentos biológicos, 
66 Gerson Simões MONTEIRO, 2004 , p. 6.

${ }^{67}$ NOSSA OPINIÃO..., 2005, p. 6.

${ }^{68}$ Marlene NOBRE, 2005, p. 6. Trata-se da presidente da Associação Médico-Espírita do Brasil, não identificada no jornal (ASSOCIAÇÃO MÉDICO-ESPÍRITA DO BRASIL, 2007). demonstra que fetos anencefálicos são natimortos cerebrais, portanto, não são nascituros. Se não são nascituros, não se pode proteger seu direito à vida, pois não são sujeitos de direitos. O mesmo raciocínio, em base jurídica, é emitido por Reis: não há vida a proteger.

Exemplo de posição religiosa está no artigo de Gerson Simões Monteiro, presidente da Fundação Cristã-Espírita Cultural Paulo de Tarso. ${ }^{66}$ Monteiro recorda a cláusula pétrea da inviolabilidade do direito à vida na Constituição e cita o Código Civil: "a personalidade civil do homem começa pelo nascimento com vida, mas a lei põe a salvo, desde a concepção, os direitos do nascituro". Questiona o argumento do direito da mulher em relação ao próprio corpo, pois o "corpo em questão não é mais o da mulher, visto que ela abriga durante a gravidez outro corpo, que não é de forma alguma uma extensão do seu". Do "ponto de vista espiritual", define-se o "crime de aborto" por impedir o espírito de passar pelas "provas necessárias ao seu progresso espiritual" na terra. O único aborto admissível é para salvar a vida da gestante, que, em nova gravidez, poderá "receber o mesmo espírito que teve a vida interrompida". Coloca-se contra o "aborto eugênico", no caso de malformação congênita do feto, da gravidez resultante de estupro e por motivos socioeconômicos. Seus argumentos reúnem a linguagem jurídica na inviolabilidade do direito à vida, direito considerado desde a concepção (um marco biológico), e o valor religioso da individualidade centrada no espírito que precisa se incorporar. O aborto do anencéfalo estaria enquadrado no rótulo de aborto eugênico.

O tema em discussão no editorial do jornal O Globo, "anencefalia e aborto", contrapõe a perspectiva da direção do informativo e uma visão divergente. A perspectiva do jornal considera omissão a lei não incluir autorização para o aborto quando o feto apresenta anencefalia, porque este morrerá antes do parto ou, se nascer com vida, durará poucos instantes ou horas, "sem vestígio de consciência". ${ }^{67}$ Contrasta o permissivo do aborto nos casos de gravidez resultante de estupro, alegando ser "brutalmente cruel" obrigar uma mulher a ter o filho assim gerado, com a situação de anencefalia, em que "a gravidez tem sempre desfecho trágico". A gestante não deve ser tratada como "criminosa" ao buscar modos de evitar prolongar o sofrimento. Esse texto, intitulado "Livre escolha", considera a gestante como sujeito. Ao feto anencefálico, em função de sua inviabilidade e da ausência de consciência, não se atribui a condição de pessoa sujeito de direitos.

A médica Marlene Nobre rebate o editorial no artigo intitulado "Outra opinião: base científica". ${ }^{68}$ Segundo Nobre, as razões contrárias ao aborto provocado não são "exclu- 
69 STRATHERN, 1992.

70 DUMONT, 1992 e 1997; e STRATHERN, 1992.

71 Dafne Dain Gandelman HOROVITZ e Murillo Campos PORTO Jr., 2005, p. 7.

\footnotetext{
72 Silvio Luiz MEDEIROS, 2005, não paginado.
}

sivamente da alçada da religião", mas "têm raízes na própria ciência". Afirma que "o zigoto e o embrião inicial são organismos humanos vivos, nos quais estão fixadas todas as bases do indivíduo adulto". O texto mescla discursos religioso e científico, apoiando-se no último, exemplo de que a descrição de fatos pela ciência serve de garantia de verdade na cosmologia ocidental moderna. ${ }^{69}$ Nobre defende a continuidade da vida humana desde a fecundação. No zigoto, "estão fixadas as bases do indivíduo adulto" (supõem-se bases genéticas), e ele manifesta personalidade própria ou memória em "imprints" (registros). Sua descrição do embrião retrata o modelo de pessoa no Ocidente Moderno, o indivíduo: ${ }^{70}$ tem competências de se "autogerir", "adequar-se a situações" e selecioná-las, "aproveitar experiências", daí sua vida pertencer "exclusivamente a ele mesmo". Apoiando-se em "razões científicas", a autora assume discurso psicologizante quanto à gestante de anencéfalo precisar de "ajuda para trabalhar seu sentimento de culpa", mas conclui com discurso religioso, incentivandoa a: "inclinar seu coração à compaixão e à misericórdia". Nobre pretende mostrar o "real significado da vida". De que consistiria esse significado: sua definição religiosa ou a reformulação da linguagem religiosa em moldes científicos?

Enquanto os textos sobre o embrião tratavam as características biológicas quase sempre de forma genérica, enfatizando o momento de início da vida ou seu caráter indiferenciado e sem individualidade, textos sobre a anencefalia a explicam com minúcias. Dafne Dain Gandelman Horovitz (médica geneticista do Departamento de Genética Médica do Instituto Fernandes Figueira, Fiocruz) e Murillo Campos Porto Jr. (médico sanitarista e presidente do Comitê de Ética Médica do Instituto Fernandes Figueira, Fiocruz) afirmam a letalidade total dessa condição e defendem o direito do casal de abreviar o sofrimento da gestação inviável por meio da antecipação do parto. ${ }^{71}$ Explicam a anencefalia - "ausência da calota craniana e degeneração do cérebro, secundárias à falha no fechamento da estrutura embrionária onde são formados cérebro e medula" - e garantem a impossibilidade de "regeneração craniana e cerebral". O raciocínio centra-se na autonomia do casal, cujo sofrimento deve ser poupado, não se cogitando atribuir o estatuto de pessoa ao anencéfalo devido à inviabilidade.

O leitor Silvio Luiz Medeiros se posiciona pela "dignidade humana" atribuída ao feto anencefálico e declara que ninguém tem o direito de decidir quem merece morrer. ${ }^{72}$ Contrasta o drama da mãe com o drama do feto, que "carrega o fardo da pena capital: a morte". Este permanece "do ponto de vista físico e biológico um ser humano". Argumenta com casos documentados de anencéfalos 
com sobrevida de um ano e com a possibilidade de os pais tratá-los como filhos e dar-lhes um enterro, coisa impossível entre os "abortados", que "vão para o lixo após serem destroçados como um frango". A dignidade humana do feto é atestada pela prática de tratamento de fetos intrau-terinos. Verifica-se, em Monteiro, que a condição humana do feto reside em sua base biológica: "ser humano do ponto de vista físico e biológico" desde o início da vida, inclusive no exemplo da medicina fetal intrauterina. Por outro lado, a dignidade humana se associa à sua recepção com amor pelos pais e ao rito do enterro, uma manifestação cultural.

\section{Considerações finais}

Houve um processo histórico pelo qual fetos e embriões se autonomizaram em relação ao corpo materno. No contexto da polêmica sobre o direito ao aborto, esses discursos foram instrumentalizados pelos grupos pró-vida para afirmar que fetos são sujeitos titulares de direitos. O surgimento da fertilização in vitro permitiu o acesso direto a embriões fora do corpo e sua utilização em pesquisa, o que desencadeou o debate sobre o estatuto do embrião extra-corporal, em continuidade parcial com a discussão sobre o aborto. Diversos temas se repetem nas representações do embrião destinado à pesquisa e do feto anencefálico. O primeiro ponto é a oposição entre pessoa e coisa, ou ser humano e objeto, muitas vezes traduzida para gestante e feto. No caso da gestação do feto anencefálico, há a oposição entre os direitos da mãe e os do feto. Os defensores de que embrião e feto constituam vidas ou sujeitos de direitos apre-sentamnos como seres autônomos, omitindo que o seu desenvolvimento com vida demanda a inserção no corpo materno.

Nesse ponto, surge o segundo tema: a viabilidade. O conceito de viabilidade desloca o foco da mãe para o feto ou embrião. A ausência de viabilidade do embrião e do feto anencefálico é argumento central para lhes recusar a condição de pessoa: não sobreviverão fora do útero materno. Se não há viabilidade, não há vida, muito menos sujeito de direitos.

Outro valor central para argumentar sobre a condição de pessoa é a individualidade. A afirmativa de que o feto tem vida individual e de que o embrião é indivíduo autônomo desde a fecundação é ponto que pretende provar a condição de pessoa. Por outro lado, a descrição do ente com termos que negam sua individualidade (em particular, características biológicas: aglomerado embriônico amorfo, conjuntos celulares pouco desenvolvidos) é meio de recusar seu estatuto de pessoa. Outro argumento invocado é a relacionalidade (oposta à individualidade), uma condição que 
${ }^{73}$ DUARTE, 1999.

\footnotetext{
${ }^{74}$ MULKAY, 1997
}

${ }^{75}$ SALEM, 1995.

76 PENNA, 2005.

77 WALDBY, 2002.

${ }^{78}$ Anne FAGOT-LARGEAUT, 2004. aponta o caráter social do ser humano. Feto ou embrião só é gente se reconhecido pela mãe, e mesmo pela sociedade, portanto, não são pessoas em abstrato e dependem do corpo materno para o seu desenvolvimento.

Associado ao valor da individualidade, o conceito de perfectibilidade ${ }^{73}$ ilumina os critérios usados para negar ou atribuir a condição de pessoa: quando se representa o embrião inicial como aglomerado amorfo de células, desfazse a impressão do indivíduo caracterizado por sua dotação genética única. O conjunto de células não seria uma pessoa, pois várias ausências o marcam: trata-se de um ser de pequena escala, desorganizado ou indiferenciado, carente de individualização; desprovido do sistema nervoso que define a capacidade racional e de autoconsciência humana; por fim, em um meio onde o seu desenvolvimento é impossível: o laboratório, e não o útero materno. O feto anencefálico define-se pela ausência do que seria a propriedade essencial da espécie humana: a racionalidade.

Designar o embrião, ou qualquer ente por outro termo, como blastocisto tem efeito retórico: mudar o nome é mudar a essência, expediente usado na Inglaterra com a designação de pré-embrião como arma para ganhar o debate parlamentar e garantir a autorização da pesquisa com embriões até o $14^{\circ}$ dia. $^{74}$

Há posições essencialistas quanto à compreensão da emergência da condição de pessoa a partir da fertilização (episódio inaugural) e ao que designa a condição de pessoa. O argumento da formação contínua de um ser a partir da fecundação baseia-se na compreensão de que o indivíduo singular está presente a partir do momento em que os cromossomas dos gametas se unem em nova totalidade. Trata-se da compreensão genética da pessoa ou sua genetização. O DNA surge na qualidade de essência do humano. ${ }^{75}$

Também se repete o questionamento da presença de vida nesses entes. Biologicamente ativo é o conceito proposto para diferenciar pessoa morta do organismo vivo, no caso da morte cerebral. ${ }^{76}$ Tal conceito é aplicável tanto a embriões de laboratório como a fetos anencefálicos. Existe tensão entre as noções de vida como biografia e de vitalidade biológica, ${ }^{77}$ o que se enquadra em ambos os casos.

Relacionado ao conceito de vida está o de dignidade humana, repetido e refutado várias vezes. O conceito de dignidade humana elaborado por Kant permeia o debate: não tratar o ser humano como um meio, mas como um fim. Segundo Anne Fagot-Largeaut, no sentido kantiano, o respeito se destina ao agente moral, um ser capaz de se autodeterminar conforme a representação que ele mesmo tem do imperativo moral. ${ }^{78}$ Nesse sentido, o embrião no estado 
79 BOLTANSKI, 2004.

${ }^{80}$ WALDBY, 2002. de blastocisto não teria autonomia moral, tampouco o anencéfalo, por isso os que dizem defender a vida se esforçam para mostrar a autonomia desses entes.

$O$ valor da vida e a dignidade humana remetem à dimensão metafísica do debate. A religião é um aspecto relacionado. Representada muitas vezes pela Igreja Católica, a religião é acusada de ser o vilão obscurantista, que impede a promoção humana através do uso de embriões para pesquisas que poderão levar a terapias ou à redução do sofrimento da gestante de anencéfalo, obrigada a levar adiante a gravidez. Todavia, embora uma minoria expressiva de artigos e cartas se posicionasse, a partir da religião, contrariamente à interrupção da gestação e ao uso de embriões, a argumentação usada na maioria vezes era de base científica (composição genética; vida a partir da fecundação). As exceções foram os textos do cardeal Dom Eugênio Sales e do espírita Gerson Simões Monteiro, que usam argumentação religiosa. O cardeal fala da sacralidade da vida humana, enquanto o espírita argumenta que o aborto é crime do "ponto de vista espiritual" por impedir a evolução do espírito na terra. Mais interessante, porém, é a mescla de discurso científico e religioso pela médica espírita Marlene Nobre.

Religiosos ou não, a tendência geral é buscar o embasamento da argumentação em dados biológicos ou naturais. Os argumentos que justificam ou recusam o uso de embriões para pesquisa e a antecipação de parto de anencéfalo coincidem em vários pontos porque são tributários da mesma configuração de valores e se fundamentam na mesma figura de pessoa: o indivíduo como valor segundo Dumont.

Embrião de laboratório e anencéfalo são tecnofetos ${ }^{79}$ e desestabilizam as fronteiras entre o humano e o não humano. Discursos da religião, do direito e da biologia, oriundos de diversos setores sociais, atribuem ou negam a condição de pessoa e, consequentemente, o estatuto de sujeito de direitos. O valor da vida é um conceito-chave para entender a polêmica em torno desse estatuto. Não se trata do processo biológico vital, mas da noção de vida como algo transcendente e sagrado. O aborto do anencéfalo e o emprego de embriões humanos como material de pesquisa representariam o fim de uma biografia, ${ }^{80}$ segundo a perspectiva pró-vida. A sacralidade de vida humana fundamenta $\circ$ valor da dignidade humana definido por Kant. A pergunta continua: trata-se de sujeitos de direitos? A vida é uma essência desses entes ou é algo a que se tem direito? A autonomização do feto em relação ao corpo materno mediante técnicas de visualização, a produção extracorporal de embriões na fertilização in vitro e a 
81 Luiz Fernando Dias DUARTE et al. (2006) referem-se ao naturalismo e ao subjetivismo. legislação que rege esses entes são processos de criação de novos sujeitos sociais. Antes embutidos no corpo materno, esses entes biológicos parecem adquirir vida própria, autônoma e individual. A análise antropológica dos pressupostos que fundamentam o debate mostra primeiramente como os argumentos antagônicos pró-vida e os relacionados ao direito de escolha partem da crença na base biológica da condição humana e da noção de pessoa como indivíduo, ambos vetores da ideologia ocidental moderna. ${ }^{81}$ Por outro lado, essa análise fornece instrumentos conceituais para desconstruir os argumentos pró-vida, invocando outros referentes biológicos ou interpretações alternativas com respeito à dignidade humana na esfera do direito que permitam questionar o estatuto de pessoa ou sujeito pleno de direitos nos casos do feto anencefálico e do embrião extracorporal. Estes não seriam dotados de essência humana, um atributo em si inerente aos sujeitos, mas o seu estabelecimento como sujeitos ou a negação desse estatuto é sempre uma construção que desafia a sociedade.

\section{Referências bibliográficas}

ASSAD, José Ebrienos. "Que venha a clonagem terapêutica". O Globo, Rio de Janeiro, p. 7, 25 abr. 2003. Opinião.

ASSOCIAÇÃO MÉDICO-ESPÍRITA DO BRASIL. Disponível em: http://www.amebrasil.org.br/html/exc.htm. Acesso em: 20 out. 2007.

AZEVEDO, Eliane. "Outra opinião: respeito à vida". O Globo, Rio de Janeiro, p. 6, 24 jul. 2003. Editorial.

BARBOSA, Rosana Machin. Desejo de filhos e infertilidade: um estudo sobre a reprodução assistida no Brasil. 1999. Tese (Doutorado em Sociologia) - Faculdade de Filosofia, Ciências e Letras, Universidade de São Paulo, São Paulo, 1999.

BARROSO, Luís Roberto. "Há luz no Supremo". O Globo, Rio de Janeiro, p. 7, 2 nov. 2004. Opinião.

. "Em defesa da vida digna: constitucionalidade e legitimidade das pesquisas com células-tronco embrionárias". In: SARMENTO, Daniel; PIOVESAN, Flávia (Orgs.). Nos limites da vida: aborto, clonagem humana, eutanásia sob a perspectiva dos direitos humanos. Rio de Janeiro: Lumen Juris, 2007. p. 241-263.

BOLTANSKI, Luc. La condition foetale: une sociologie de l'engendrement et de l'avortement. Paris: Gallimard, 2004.

BUSH e a clonagem. O Globo, Rio de Janeiro, p. 6, 12 abr. 2002. Editorial.

CANNELL, Fenella. "Concepts of Parenthood: The Warnock Report, the Gillick Debate, and Modern Myths". American Ethnologist, v. 4, n. 17, p. 667-686, 1990. 
CAVALCANTI, Nicolau da Rocha. "Cartas dos Leitores". O Globo, Rio de Janeiro, p. 6, 4 dez. 2001.

CESARINO, Letícia Maria Costa da Nóbrega. Acendendo as luzes da ciência para iluminar o caminho do progresso: uma análise simétrica de Lei de Biossegurança brasileira. 2006. Dissertação (Mestrado em Antropologia Social) - Programa de Pós-Graduação em Antropologia Social, Universidade de Brasília, Brasília, 2006.

CHAZAN, Lilian Krakowski. "Meio quilo de gente": um estudo antropológico sobre ultra-som obstétrico. Rio de Janeiro: Fiocruz, 2007.

CLONAGEM terapêutica. Folha de S. Paulo, p. A2, 6 jun. 2004. Opinião.

CNBB forma assessoria em bioética. Conferência Nacional dos Bispos do Brasil. Disponível em: http://www.cnbb.org.br/ index.php?op=pagina\&chaveid=236.013. Acesso em: 20 out. 2007.

CONFERÊNCIA NACIONAL DOS BISPOS DO BRASIL. Boletim Notícias, n. 20, 1825, 16 jun. 2005. Disponível em: http:// w w w . c n b b . o r g . b r / index. php?op $=$ pagina\&chaveid $=240 a 000013$. Acesso em: 20 out. 2007.

CONKLIN, Beth A.; MORGAN, Lynn Marie. "Babies Bodies and Production of Personhood in North America and a Native Amazonian Society". Ethos, v. 24, n. 4, p. 657-694, 1996. COSTA, Marcos Paulo Castilho. "Cartas dos Leitores". O Globo, Rio de Janeiro, p. 6, 10 abr. 2004.

COWAN, Ruth Schwartz. "Genetic Technology and Reproductive Choice: An Ethics for Autonomy". In: KEVLES, Daniel J.; HOOD, Leroy (Eds.). The Code of Codes: Scientific and Social Issues in the Human Genome Project. Cambridge: Harvard University Press, 1992. p. 244-263.

DUARTE, Enio Porto. "Cartas dos Leitores". O Globo, Rio de Janeiro, p. 6, 13 dez. 2001.

DUARTE, Luiz Fernando Dias. "O império dos sentidos: sensibilidade, sensualidade e sexualidade na cultura ocidental moderna". In: HEILBORN, Maria Luiza (Org.). Sexualidade: o olhar das ciências sociais. Rio de Janeiro: Jorge Zahar, 1999. p. 21-30.

DUARTE, Luiz Fernando Dias et al. "Família, reprodução e ethos religioso: subjetivismo e naturalismo como valores estruturantes". In: DUARTE, Luiz Fernando Dias et al. (Orgs.). Família e religião. Rio de Janeiro: Contracapa, 2006. p. 15-49.

DUMONT, Louis. Ensaios sobre o individualismo: uma perspectiva antropológica sobre a ideologia moderna. Lisboa: Dom Quixote, 1992.

Homo Hierarchicus: o sistema de castas e suas implicações. 2. ed. São Paulo: Edusp, 1997. 
FAGOT-LARGEAUT, Anne. "Embriões, células-tronco e terapias celulares: questões filosóficas e antropológicas". Estudos Avançados, v. 18, n. 51, p. 227- 245, 2004.

FERNANDES, Maíra Costa. "Interrupção de gravidez de feto anencefálico: uma análise constitucional”. In: SARMENTO, Daniel; PIOVESAN, Flávia (Orgs.). Nos limites da vida: aborto, clonagem humana, eutanásia sob a perspectiva dos direitos humanos. Rio de Janeiro: Lumen Juris, 2007. p. 111-158.

FERREIRA, Marco Aurélio Gonçalves. "Cartas dos Leitores". O Globo, Rio de Janeiro, p. 6, 18 out. 2004.

FRANKLIN, Sarah. "Fetal Fascinations: New Dimensions to the Medical-scientific Construction of Fetal Personhood". In: FRANKLIN, Sarah; LURY, Celia; STACEY, Jackie (Eds.). OffCentre: Feminism and Cultural Studies. Lancaster: HarperCollins Publishers, 1991. p. 190-205.

FYFE, Wendy. "Abortion Acts: 1803 to 1967". In: FRANKLIN, Sarah, LURY, Celia; STACEY, Jackie (Eds.). Off-Centre: Feminism and Cultural Studies. Lancaster: HarperCollins Publishers, 1991. p. 160-174.

GARCIA, Eloi S. "Pesquisa, perigo e progresso". O Globo, Rio de Janeiro, p. 7, 18 abr. 2003. Opinião.

GARRAFA, Volnei. "A ética dos clones". O Globo, Rio de Janeiro, p. 50, 2 dez. 2001. Ciência e Vida.

GIANOTTI, Rolland. "Esperando Emanuel: a angústia da grávida que gera um bebê desenganado por médicos". O Globo, Rio de Janeiro, 10 fev. 2003. Rio.

GUIMARÃES, Rafael Leite. "Cartas dos Leitores". O Globo, Rio de Janeiro, p. 6, 6 nov. 2004.

HOROVITZ, Dafne Dain Gandelman; PORTO Jr, Murillo Campos. "Elas têm o direito de sofrer menos". O Globo, Rio de Janeiro, p. 7, 13 maio 2005. Opinião.

HUBBARD, Ruth. The Politics of Women's Biology. New Brunswick: Rutgers University Press, 1990.

HURST, Jane. Uma história não contada: a história das idéias sobre o aborto na Igreja Católica. São Paulo: Católicas pelo Direito de Decidir, 2000.

JOBIM, Everton N. "Cartas dos Leitores". O Globo, Rio de Janeiro, p. 6, 14 abr. 2002.

JUNKER-KENNY, Maureen. "O status moral do embrião". Concilium, v. 275, n. 2, p. 60-72, 1998.

LAUS, Antônio Carlos de Oliveira. "Cartas dos Leitores". O Globo, Rio de Janeiro, p. 6, 14 abr. 2002.

LEAL, Ondina Fachel; LEWGOY, Bernardo. "Pessoa, aborto e contracepção". In: . (Org.). Corpo e significado: ensaios de antropologia social. Porto Alegre: Editora da Universidade, 1995. p. 57-75.

LUNA, Naara. "A clonagem como problema e seus lugares comuns". Ciência Hoje, v. 30, n. 176, p. 45-47, out. 2001. 
. "As novas tecnologias reprodutivas e o estatuto do embrião: um discurso do magistério da Igreja Católica sobre a natureza". Gênero, v. 3, n. 1, p. 83-100, 2002.

"A personalização do embrião humano: da transcendência na Biologia". Mana: Estudos de Antropologia Social, v. 13, n. 2, 2007.

MATOS, Sérgio Bezerra de. "Cartas dos Leitores". O Globo, Rio de Janeiro, p. 6, 12 nov. 2004.

MEDEIROS, Silvio Luiz. "Aborto em fetos anencéfalos: uma tragédia para todos nós". Jornal do Brasil, Rio de Janeiro, 22 maio 2005. Fórum dos Leitores. Não paginado.

MELO, Cristiane. "Perigoso precedente". O Globo, Rio de Janeiro, p. 7, 4 nov. 2005. Opinião.

MONTEIRO, Gerson Simões. "Outra opinião: inadmissível". O Globo, Rio de Janeiro, p. 6, 19 dez. 2004.

MORGAN, Lynn. "Embryo Tales". In: FRANKLIN, Sarah; LOCK, Margaret (Eds.). Remaking Life and Death: Toward an Anthropology of Biosciences. Santa Fe: School of American Research Press; Oxford: James Currey, 2003. p. 261-291.

MULKAY, Michael. The Embryo Research Debate: Science and the Politics of Reproduction. Cambridge: Cambridge University Press, 1997.

NOBRE, Marlene. "Outra opinião: base científica". O Globo, Rio de Janeiro, p. 6, 29 abr. 2005.

NOSSA OPINIÃO: esperança médica. O Globo, Rio de Janeiro, p. 6, 24 jul. 2003. Editorial.

NOSSA OPINIÃO: livre escolha. O Globo, Rio de Janeiro, p. 6 , 29 abr. 2005. Editorial.

PENA, Sergio Danilo. "Clonagem criará bebê com duas mães: geneticista acha que clones de embriões abrem perspectivas inéditas na medicina". O Globo, Rio de Janeiro, p. 24, 3 dez. 2001. Ciência e Vida.

PENNA, Maria Lúcia Fernandes. "Anencefalia e morte cerebral (neurológica)". Physis: Revista de Saúde Coletiva, v. 15, n. 1, p. 950-106, 2005.

PEREIRA, Lygia Veiga. "Ecos de um passado de trevas". O Globo, Rio de Janeiro, p. 7, 19 jul. 2004. Opinião.

PRAXEDES, Herbert. "Cartas dos Leitores". O Globo, Rio de Janeiro, p. 6, 26 set. 2003.

. "Cartas dos Leitores". O Globo, Rio de Janeiro, p. 6, 10 nov. 2004.

REHEN, Stevens; MUOTRI, Alysson. "A chance do Brasil". O Globo, Rio de Janeiro, p. 7, 4 nov. 2005. Opinião.

REIS, Fernando Cesar Magalhães. "Cartas dos Leitores". O Globo, Rio de Janeiro, p. 6, 12 nov. 2004.

RODRIGUES, Maria do Carmo de Souza. "Outra opinião: limites". O Globo, Rio de Janeiro, p. 6, 11 out. 2004. 
SALEM, Tania. "O princípio do anonimato na Inseminação Artificial com Doador (IAD)". Physis, Revista de Saúde Coletiva, v. 5, n. 1, p. 33-68, 1995.

. "As novas tecnologias reprodutivas: o estatuto do embrião e a noção de pessoa". Mana, v. 3, n. 1, p. 7594, 1997.

SALES, Dom Eugênio. "Um crime contra a vida". O Globo, Rio de Janeiro, p. 7, 10 jul. 2004. Opinião.

STRATHERN, Marilyn. Reproducing the Future: Essays on Anthropology, Kinship and the New Reproductive Technologies. Manchester: Manchester University Press, 1992.

TURNER, Victor Witter. Schism and Continuity in an African Society: A Study of Ndembu Village Life. Manchester: Manchester University Press, 1957.

WALDBY, Catherine. "Stem Cells, Tissue Cultures and the Production of Biovalue". Health, v. 6, n. 3, p. 305-323, 2002.

[Recebido em fevereiro de 2008 e aceito para publicação em dezembro de 2008]

\begin{abstract}
Anencephalic Fetuses and Research Embryos: Subjects of Rights?
Abstract: The present article analyzes the emergence of social subjects in the form of beings which had previously been embedded in mother's bodies and which have later become defined and circumscribed by biomedicine: extracorporal embryos, created by in vitro fertilization, and anencephalic fetuses. The embryos were at the center of the controversy regarding their use in scientific research during the debates for the approval of Brazil's new biosecurity law. Anencephalic fetuses became the center of a debate regarding the relaxing of Brazil's abortion laws. This article analyzes mass media news stories provided mostly by a systematic review of articles published in O Globo newspaper between 2000 and 2005 in order to recover the arguments presented in these debates. The arguments to justify or ban embryo research or to anticipate the birth of anencephalic fetuses coincide, in large part, because they are derived from the same value configuration and are founded upon the person: Dumont's individual-as-value.
\end{abstract}

Key Words: Human Embryo; Anencephalous; Abortion; Life; Personhood. 